\title{
RESEARCH OF FOAM FORMERS AND CONCRETE ON THEIR BASIS FOR PRODUCTION OF PRODUCTS OF NON-AUTOCLAVE HARDENING AND MONOLITHIC CONCRETE
}

\author{
Lviv Polytechnic National University, \\ Department of Building Production, \\ vasililiv1960@gmail.com
}

(C) Iliv V., Iliv Ch.-Dzv., 2020

Production of foam concrete products and monolithic concreting from them requires foaming agents that have the properties of the obtained foam with a sufficient value of its criteria (multiplicity of foaming, stability of foam for a certain period of time); its compatibility with Portland cement and its hydration products; with hydrated lime, etc. Insufficient properties of the foam can be compensated by the introduction of corrective and stabilizing additives. Although the studied foaming agents are not always environmentally friendly products, but their low concentration in foam concrete creates a precedent for their indispensability in the production process.

The investigated foaming agents practically do not differ in multiplicity and stability at their use in $1 \%$ solution. The best technological properties are inherent in the foam obtained from the foaming agent of the PEAS brand. The introduction of the additive partially increases the multiplicity and stability of the foam. In addition, it acts as an accelerator of the set of strength on the hardening of foam concrete, which increases the reversibility of metal molds and accelerates the load of the monolith. It was found that foam concrete compositions that do not contain additives are mainly prone to delamination and shrinkage, so in the manufacture of samples from them, much attention was paid to the quality of the obtained samples. This indicates that the additive is not only a foam stabilizer, it also stabilizes the foam concrete mixtures obtained on their basis.

Key words: foam, foaming agent, foam concrete, turbulent mixer, foaming multiplicity, foam stability over time, compressive strength, average density.

\section{Introduction}

The production of autoclaved foam concrete, in comparison with autoclaved foam or aerated concrete, reduces the cost of insulation of roofs of houses and walls and reduces the time and cost of construction. This is achieved by saving electricity in the production of foam concrete, cheap components of foam concrete, reducing the number of workers and the lack of complex construction equipment.

Due to the cellular structure, foam concrete has low heat transfer, which means that in most cases there is no need for additional insulation in floors and walls (Bolshakov, Martynenko (2005). The acoustic properties of foam concrete are such that sound is absorbed without reflection, unlike walls made of heavy concrete or brick. Therefore, foam concrete is often used as a sound insulation layer on structural concrete slabs to limit the noise transmission of floors. Foam concrete, unlike mineral wool and foams, which lose their properties over time, only improves its thermal insulation properties and strength, which is due to its long internal maturation (Zhaglin, Artsybashev 2005).

\section{Target of this article}

The filling of the market of Western Ukraine with various foaming agents of domestic and foreign production requires a study of the properties of foams based on them. Especially important for them are the multiplicity of foaming and the stability of the foam over a period of time. Comparative characteristics of 
the properties of foaming agents facilitate their use in the production of foam concrete (Iliv, Kahanov, Nazarevych 2005). Development of efficient from a production, economic and operational point of view composition of foam concrete masses based on raw materials of Western Ukraine, based on the conditions of easy availability of raw materials, for monolithic concreting and obtaining products without autoclave hardening is the second part of research.

\section{Techniques used}

Preparation of foam for the study was carried out on a laboratory mixer with a speed of more than $2000 \mathrm{rpm}$ To improve the turbulence of mixing, a four-bladed propeller is installed on the shaft, in which the edges of the blades are bent at an angle of $5-10^{\circ}$. The volume of the foam was determined by the geometric dimensions of the volume it occupied in a standard vessel in the form of a truncated cone. The foam was mixed for at least 30 seconds until the volume was completely stabilized.

The main technological parameters of foam for foam concrete are the multiplicity of foaming and stability of the foam over a period of time (Yurchenko, Sorokolat 2006). The multiplicity of foaming ( $\left.\mathbf{K}_{\mathbf{P}}\right)$ is estimated by the multiplicity coefficient and is determined by the ratio of the volumes of foam and foaming agent.

The coefficient of stability of the foam by volume characterizes the stability of the foam before its use in the preparation of concrete mixes. To obtain high-quality foam concrete requires a duration of foam stability of at least 10-15 minutes. The coefficient of stability of the foam $\left(\mathbf{K}_{\mathbf{P}}^{\mathbf{v}}\right)$ is defined by the total volume as the ratio of the variable volume of foam over time to the initial volume of foam.

Preparation of the foam concrete mixture was carried out by separate technology in two stages. At the first stage, the foam was prepared on a mixer, the soluble mixture was mixed separately. In the second stage, they were mixed. Because the conical container was insufficient to mix them, the foam was poured approximately exactly into two equivalent conical containers, after which half of the soluble mixture was added to it approximately evenly. Both mixtures were mixed on a mixer until smooth. Mixtures of foam concrete were poured into a container in which a mortar mixture was prepared, where the mixture was mediated by stirring with a spatula. The mixture was poured into molds. Standard beams measuring $4 \times 4 \times 16 \mathrm{~cm}$ were chosen as the basic samples for the strength test, which are used to determine the brand properties of the binder materials and the strength characteristics of the solutions.

The higher the multiplicity of foaming, the smaller the negative impact of the foaming agent on the hydration process of cements, because as each surfactant foaming agents slow down the hydration of cements and increase the hardening time and slow down the strength of cements in foam concrete. Such foams depend on a number of factors, including the type of foaming agent, the method of foaming and the capabilities of the foam generator (Shakhova Chernositova 2005) (Bolshakov, Martynenko 2001).

The results of the study of the multiplicity and stability of foam over time for 12 minutes are given in Tables 1 and 2. They also show the results obtained on one of the foaming agents, when additionally introduced a complex action additive that increased the multiplicity of foam along with its stabilization and, which is the solidification of the accelerator. These foaming agents include foaming agents known under the "Penostrem" brand and TEAS and PEAS foaming agents, which are used by firefighters and for flushing main pipelines (Borovikov, Slutskaya 2014).

The one percent solution was chosen for reasons, firstly, through the relevant recommendations of dealers, and secondly, to reduce the test to comparative results.

According to Table 1 it is necessary to note a slight difference in the multiplicity of foams obtained from $1 \%$ solution of foaming agents. It is necessary to note slightly better foaming for the PEAS brand and the foamer of the "Penostrem" brand of dark color. The introduction of a complex additive allows to increase the multiplicity of foam by almost one unit, which for the TEAS brand is almost $21 \%$.

The stability of the foams obtained from these foaming agents, as can be seen from Table. 2, does not change significantly for 12 minutes. The PEAS brand foaming agent not only has the highest foaming 
rate, but also forms a slightly more stable foam over time compared to other foaming agents. The introduction of the additive, as seen in the example of the foaming agent brand TEAS, partially stabilizes the foam over time. The coefficient of stability for TEAS increased by $4 \%$ after 12 minutes. The foamer of the Penostrem brand of dark color possesses not only high multiplicity of foaming, but also forms foam much more stable in time in comparison with others. The introduction of the additive to the foaming agent of the TEAS brand partially stabilizes the technical foam over time. The coefficient of stability for him increased after 12 minutes from 92.6 to $96.3 \%$.

Table 1

\section{Study of foam multiplicity}

\begin{tabular}{|c|c|c|c|c|c|}
\hline \multirow{2}{*}{\begin{tabular}{c} 
Type of foaming solution \\
\cline { 2 - 6 }
\end{tabular}} & Fresh foam & After 3 min. & After 6 min. & After 9 min. & After 12 min. \\
\hline $\begin{array}{c}1 \% \text { solution of light foaming agent } \\
\text { "Penostrem" }\end{array}$ & 3.89 & 3.81 & 3.76 & 3.76 & 3.72 \\
\hline $\begin{array}{c}1 \% \text { solution of dark foaming agent } \\
\text { "Penostrem" }\end{array}$ & 4.43 & 4.34 & 4.30 & 4.25 & 4.21 \\
\hline $1 \%$ solution TEAS & 4.6 & 3.95 & 3.89 & 3.79 & 3.76 \\
\hline $1 \%$ solution PEAS & 4.60 & 4.56 & 4.53 & 4.49 & 4.47 \\
\hline $1 \%$ solution TEAS + stabilizer & 4.91 & 4.87 & 4.82 & 4.79 & 4.73 \\
\hline
\end{tabular}

Table 2

Study of foam multiplicity

\begin{tabular}{|c|c|c|c|c|c|}
\hline \multirow{2}{*}{ Type of foaming solution } & \multicolumn{5}{|c|}{ Value $\mathrm{K}_{\mathrm{P}}$} \\
\cline { 2 - 6 } & Fresh foam & After 3 min & After 6 min. & After 9 min & After 12 min \\
\hline $\begin{array}{c}\text { 1 \% solution of light foaming agent } \\
\text { "Penostrem" }\end{array}$ & 1.00 & 0.979 & 0.967 & 0.967 & 0.956 \\
\hline $\begin{array}{c}\text { 1\% solution of dark foaming agent } \\
\text { "Penostrem" }\end{array}$ & 1.00 & 0.980 & 0.971 & 0.959 & 0.950 \\
\hline $1 \%$ solution TEAS & 1.00 & 0.973 & 0.958 & 0.933 & 0.926 \\
\hline $1 \%$ solution PEAS & 1.00 & 0.991 & 0.985 & 0.976 & 0.972 \\
\hline $1 \%$ solution TEAS + stabilizer & 1.00 & 0.992 & 0.982 & 0.976 & 0.963 \\
\hline
\end{tabular}

Therefore, the studied foaming agents practically do not differ in multiplicity and stability when used in $1 \%$ solution. The best properties are inherent in the foam obtained on the basis of the foaming agent of the PEAS brand. The introduction of a complex additive can partially increase the multiplicity and stability of the above-mentioned foam solution. In addition, the tested additive affects the hardening of foam concrete as an accelerator of the set of strength, which increases the reversibility of metal molds and accelerates the rate of monolithic concreting (Iliv, Kahanov 2005). This factor is of practical importance for the serial production of cellular concretes of natural hardening (Merkin, Kobidze 1988).

The first batch of foam concrete samples was prepared on the basis of technical foam obtained from the foamer brand TEAS, which is the most available on the market. As raw materials were used additive-free cement brand 400 produced by PJSC "Ivano-Frankivskcement", local sand of the Mykolayiv deposit, dry ash of Burshtyn TPP, sawdust of the same PJSC "Ivano-Frankivskcement".

The compositions of the masses of foam concrete are given in Tables 3 and 4.

According to the density, foam concrete of grade 700 was chosen, because according to this indicator such foam concrete belongs to structural and heat-insulating foam concrete, along with good heat-insulating indicators it has sufficient strength. The composition No. 1, which contains 350 grams of cement and 215 grams of sand, was chosen as the base. All other compositions of foam concrete were obtained, either by the introduction of a complex additive, or by partial replacement of sand with ash and dust (Iliv, Iliv 2019). 
After pouring the molds, the samples were kept in molds until gaining the necessary plastic strength, which allowed their disassembly. It should be noted that the molds with samples of foam concrete from masses that do not label additives were disassembled the next day, about a day after pouring. In contrast, samples containing the additive quickly gained plastic strength, so the molds with them were disassembled approximately 10-12 hours after pouring. The samples were mounted on a stand in a box made of galvanized sheet metal, which was closed with a lid. Water was poured on the bottom of the box, evaporation of which created conditions for normal hardening of foam concrete samples.

Table 3

\section{Compositions of masses of foam concrete of the first pouring}

\begin{tabular}{|c|c|c|c|c|c|c|c|c|}
\hline \multirow{2}{*}{$\begin{array}{l}\text { No. } \\
\text { in. } \\
\text { od. }\end{array}$} & \multirow{2}{*}{$\begin{array}{l}\text { The cost of the } \\
\text { foaming } \\
\text { solution, ml }\end{array}$} & \multirow{2}{*}{$\begin{array}{l}\text { Foam } \\
\text { costs, ml }\end{array}$} & \multirow{2}{*}{$\begin{array}{l}\text { The content of the } \\
\text { foam-thief in the } \\
\text { initial solution }\end{array}$} & \multicolumn{5}{|c|}{ Consumption of materials for solution preparation, $g$} \\
\hline & & & & cement & sand & $\begin{array}{c}\text { ash, } \\
\text { (\% replacement) }\end{array}$ & $\begin{array}{c}\text { sawdust, } \\
\text { (\% replacement) }\end{array}$ & water \\
\hline 1 & 150 & 608 & $1.5 \mathrm{ml}$ TEAS & 350 & 215 & - & & 205 \\
\hline 2 & 150 & 737 & $\begin{array}{c}1.5 \mathrm{ml} \text { TEAS }+5 \mathrm{ml} \\
\text { liquid glass }\end{array}$ & 350 & 215 & - & & 205 \\
\hline 3 & 150 & 608 & $1.5 \mathrm{ml}$ TEAS & 350 & 150.5 & $64.5(30 \%)$ & & 205 \\
\hline 4 & 150 & 737 & $\begin{array}{c}1.5 \mathrm{ml} \text { TEAS }+5 \mathrm{ml} \\
\text { liquid glass }\end{array}$ & 350 & 150.5 & $64.5(30 \%)$ & & 205 \\
\hline 5 & 150 & 608 & $1.5 \mathrm{ml}$ TEAS & 350 & 172 & - & $43(20 \%)$ & 205 \\
\hline 6 & 150 & 737 & $\begin{array}{c}1.5 \mathrm{ml} \text { TEAS }+5 \mathrm{ml} \\
\text { liquid glass }\end{array}$ & 350 & 172 & - & $43(20 \%)$ & 205 \\
\hline
\end{tabular}

Compositions 2, 4, 6 differ from compositions 1, 2, 3 only by the introduction into the foaming agent of liquid glass.

Table 4

\section{Compositions of masses of foam concrete of the second pouring}

\begin{tabular}{|c|c|c|c|c|c|c|c|c|}
\hline \multirow{2}{*}{$\begin{array}{l}\text { No. } \\
\text { in. } \\
\text { od. }\end{array}$} & \multirow{2}{*}{\begin{tabular}{|c|} 
The cost of the \\
foaming \\
solution, $\mathrm{ml}$
\end{tabular}} & \multirow{2}{*}{$\begin{array}{l}\text { Foam } \\
\text { costs, } \mathrm{ml}\end{array}$} & \multirow{2}{*}{$\begin{array}{l}\text { The content of the } \\
\text { foam-thief in the } \\
\text { initial solution }\end{array}$} & \multicolumn{5}{|c|}{ Consumption of materials for solution preparation, $g$} \\
\hline & & & & cement & sand & $\begin{array}{c}\text { ash, } \\
\text { (\% replacement) }\end{array}$ & $\begin{array}{c}\text { sawdust, } \\
\text { (\% replacement) }\end{array}$ & water \\
\hline 1 & 150 & 737 & $\begin{array}{c}1.5 \mathrm{ml} \text { TEAS }+5 \mathrm{ml} \\
\text { liquid glass }\end{array}$ & 350 & 172 & 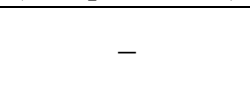 & $\begin{array}{c}43 \\
(20 \%)\end{array}$ & 205 \\
\hline 2 & 150 & 737 & $\begin{array}{c}1.5 \mathrm{ml} \text { TEAS }+5 \mathrm{ml} \\
\text { liquid glass }\end{array}$ & 350 & 139.75 & $\begin{array}{c}64.5 \\
(30 \%) \\
\end{array}$ & $\begin{array}{l}10.75 \\
(5 \%) \\
\end{array}$ & 205 \\
\hline 3 & 150 & 737 & $\begin{array}{c}1.5 \mathrm{ml} \text { TEAS }+5 \mathrm{ml} \\
\text { liquid glass }\end{array}$ & 350 & 129 & $\begin{array}{c}64.5 \\
(30 \%)\end{array}$ & $\begin{array}{c}21.5 \\
(10 \%)\end{array}$ & 205 \\
\hline 4 & 150 & 737 & $\begin{array}{c}1 ., 5 \mathrm{ml} \text { TEAS }+5 \mathrm{ml} \\
\text { liquid glass }\end{array}$ & 350 & 118.25 & $\begin{array}{c}64.5 \\
(30 \%) \\
\end{array}$ & $\begin{array}{c}32.5 \\
(15 \%) \\
\end{array}$ & 205 \\
\hline 5 & 150 & 737 & $\begin{array}{c}1.5 \mathrm{ml} \text { TEAS }+5 \mathrm{ml} \\
\text { liquid glass }+1 \mathrm{ml} \\
\text { additive }\end{array}$ & 350 & 150.5 & $\begin{array}{c}64.5 \\
(30 \%)\end{array}$ & & 180 \\
\hline 6 & 150 & 737 & $\begin{array}{l}1.5 \mathrm{ml} \text { TEAS }+5 \mathrm{ml} \\
\text { liquid glass }+1 \mathrm{ml} \\
\text { additive }\end{array}$ & 350 & 150.5 & $\begin{array}{c}64.5 \\
(30 \%)\end{array}$ & & 150 \\
\hline
\end{tabular}

After the results of the compressive strength test and determination of the average density of the first pour, the second pour was performed to clarify the results of the first due to delamination and shrinkage of the foam concrete mixture and to continue replacing sand and reducing water content in mortar. As a result of research on the average density and compressive strength, the following results were obtained, which are given in Table. 5 and 6. 
Inadequate test results were obtained due to foam shrinkage and stratification of the foam concrete mixture in the first pouring (see notes in Tables 5 and 6).

The strength of foam concrete samples was determined for a period of 14 days, which allowed to judge the significance of the acceleration of the set of strength due to the introduction of the additive, as well as for 28 days according to the requirements of branded strength.

As can be seen from the notes in Table 5, the masses that do not contain additives are mainly prone to delamination, and sometimes shrinkage, so in the manufacture of samples from them great attention was paid to the quality of the obtained beams, sometimes their manufacture was repeated. This indicates that the additive is not only a stabilizer of technical foam, it also stabilizes well foam mixtures.

Table 5

Study of the average density and compressive strength of the 1st pour

\begin{tabular}{|c|c|c|c|c|c|c|c|}
\hline \multirow{2}{*}{$\begin{array}{c}\text { No. } \\
\text { in. } \\
\text { od }\end{array}$} & \multicolumn{2}{|c|}{$\begin{array}{c}\text { Strength for } 14 \text { days, } \\
\mathrm{kgf} / \mathrm{cm}^{2}\end{array}$} & \multicolumn{2}{|c|}{$\begin{array}{c}\text { Strength for } 28 \text { days, } \\
\mathrm{kgf} / \mathrm{cm}^{2}\end{array}$} & \multicolumn{2}{|c|}{ Average density, $\mathrm{kg} / \mathrm{m}^{3}$} & \multirow[b]{2}{*}{ Notes } \\
\hline & $\begin{array}{l}\text { Individual } \\
\text { samples }\end{array}$ & Average value & $\begin{array}{l}\text { Individual } \\
\text { samples }\end{array}$ & Average value & $\begin{array}{l}\text { Individual } \\
\text { samples }\end{array}$ & Average value & \\
\hline 1 & $\begin{array}{l}4.72 \\
3.60 \\
3.76 \\
\end{array}$ & 4.03 & $\begin{array}{l}4.24 \\
3.84 \\
3.52 \\
\end{array}$ & 3.87 & $\begin{array}{l}734 \\
750 \\
742 \\
\end{array}$ & 742 & Bundling \\
\hline 2 & $\begin{array}{l}5.6 \\
5.6\end{array}$ & 5.6 & $\begin{array}{l}16.04 \\
13.36\end{array}$ & 14.7 & $\begin{array}{l}820 \\
820\end{array}$ & 820 & \\
\hline 3 & $\begin{array}{l}4.07 \\
4.01 \\
3.90\end{array}$ & 3.99 & $\begin{array}{l}4.16 \\
5.44 \\
5.28\end{array}$ & 4.96 & $\begin{array}{l}742 \\
801 \\
820\end{array}$ & 788 & Bundling \\
\hline 4 & $\begin{array}{l}6.88 \\
6.32 \\
5.88 \\
\end{array}$ & 6.36 & $\begin{array}{l}15.76 \\
12.24 \\
19.18\end{array}$ & 15.74 & $\begin{array}{l}769 \\
763 \\
775\end{array}$ & 769 & \\
\hline 5 & $\begin{array}{l}4.08 \\
4.88 \\
4.00\end{array}$ & 4.32 & $\begin{array}{l}6.16 \\
6.64\end{array}$ & 6.4 & $\begin{array}{l}750 \\
764 \\
748\end{array}$ & 754 & $\begin{array}{l}\text { Bundling } \\
\text { Coagulation }\end{array}$ \\
\hline 6 & $\begin{array}{l}4.99 \\
5.09\end{array}$ & 5.04 & $\begin{array}{l}6.70 \\
7.01\end{array}$ & 6.85 & $\begin{array}{l}759 \\
734\end{array}$ & 746 & Bundling \\
\hline
\end{tabular}

In addition, a comparative analysis of the strength of the beams shows that the introduction of a complex additive helps to increase the compressive strength. This is especially noticeable for samples at the age of 14 days. Therefore, this additive manifests itself both as an accelerator of hardening and strength.

Stratification of foam concrete mixtures significantly reduces the compressive strength of foam concrete, especially significantly for 28 days, which caused the need to adjust the composition of foam concrete. The role of the foam stabilizer was played by the introduction of a solution of liquid glass as a plasticizer.

Partial shrinkage of foam concrete mixtures causes an increase in the average density of foam concrete.

The strength of foam concrete samples was determined for a period of 14 days, which allowed to judge the significance of the acceleration of the set of strength due to the introduction of the additive, as well as for 28 days according to the requirements of branded strength.

As can be seen from the notes in Table 5, the masses that do not contain additives are mainly prone to delamination, and sometimes shrinkage, so in the manufacture of samples from them great attention was paid to the quality of the obtained beams, sometimes their manufacture was repeated. This indicates that the additive is not only a stabilizer of technical foam, it also stabilizes well foam mixtures. 
In addition, a comparative analysis of the strength of the beams shows that the introduction of a complex additive helps to increase the compressive strength. This is especially noticeable for samples at the age of 14 days. Therefore, this additive manifests itself both as an accelerator of hardening and strength.

Stratification of foam concrete mixtures significantly reduces the compressive strength of foam concrete, especially significantly for 28 days, which caused the need to adjust the composition of foam concrete. The role of the foam stabilizer was played by the introduction of a solution of liquid glass and plasticizer.

Partial shrinkage of foam concrete mixtures causes an increase in the average density of foam concrete.

Table 6

Study of the average density and compressive strength of the 2nd pour

\begin{tabular}{|c|c|c|c|c|c|c|c|}
\hline \multirow{2}{*}{$\begin{array}{l}\text { No. } \\
\text { in. } \\
\text { od }\end{array}$} & \multicolumn{2}{|c|}{$\begin{array}{l}\text { Strength for } 14 \text { days, } \\
\mathrm{kgf} / \mathrm{cm}^{2}\end{array}$} & \multicolumn{2}{|c|}{$\begin{array}{c}\text { Strength for } 28 \text { days, } \\
\mathrm{kgf} / \mathrm{cm}^{2}\end{array}$} & \multicolumn{2}{|c|}{ Average density, $\mathrm{kg} / \mathrm{m}^{3}$} & \multirow[b]{2}{*}{ Notes } \\
\hline & $\begin{array}{c}\text { Individual } \\
\text { samples }\end{array}$ & Average value & $\begin{array}{c}\text { Individual } \\
\text { samples }\end{array}$ & Average value & $\begin{array}{c}\text { Individual } \\
\text { samples }\end{array}$ & Average value & \\
\hline \multirow{3}{*}{1} & 17.44 & \multirow{3}{*}{19.25} & 22.2 & \multirow{3}{*}{21.8} & 1020 & \multirow{3}{*}{999} & \multirow{3}{*}{ Часткове зсідання } \\
\hline & 18.82 & & 23.1 & & 982 & & \\
\hline & 21.50 & & 20.1 & & 996 & & \\
\hline \multirow{3}{*}{2} & 10.50 & \multirow{3}{*}{11.42} & 14.1 & \multirow{3}{*}{14.9} & 703 & \multirow{3}{*}{710} & \\
\hline & 11.06 & & 15.4 & & 723 & & \\
\hline & 12.69 & & 15.2 & & 703 & & \\
\hline \multirow{3}{*}{3} & 7.61 & \multirow{3}{*}{11.72} & 16.8 & \multirow{3}{*}{16.7} & 929 & \multirow{3}{*}{964} & \\
\hline & 11.28 & & 15.2 & & 1056 & & \\
\hline & 15.98 & & 18.2 & & 908 & & \\
\hline \multirow{3}{*}{4} & 10.57 & \multirow{3}{*}{11.28} & 16.7 & \multirow{3}{*}{16.9} & 793 & \multirow{3}{*}{736} & \multirow{3}{*}{$\begin{array}{l}\text { Дрібнопориста } \\
\text { структура поверхні }\end{array}$} \\
\hline & 11.28 & & 17.2 & & 742 & & \\
\hline & 11.98 & & 16.8 & & 742 & & \\
\hline \multirow{3}{*}{5} & 7.56 & \multirow{3}{*}{10.41} & 15.8 & \multirow{3}{*}{15.6} & 692 & \multirow{3}{*}{730} & \multirow{3}{*}{--“-- } \\
\hline & 10.08 & & 15.5 & & 716 & & \\
\hline & 13.60 & & 15.5 & & 781 & & \\
\hline \multirow{3}{*}{6} & 12.69 & \multirow{3}{*}{15.68} & 18.9 & \multirow{3}{*}{19.9} & 801 & \multirow{3}{*}{820} & \multirow{3}{*}{--“"-- } \\
\hline & 17.09 & & 20.2 & & 820 & & \\
\hline & 17.27 & & 20.5 & & 840 & & \\
\hline
\end{tabular}

\section{Conclusions}

1. Stratification of the foam concrete mixture causes a significant decrease in the strength of foam concrete, and coagulation - an increase in density.

2. Increasing the viscosity of the foam concrete mixture due to the reduction of water contributes to the increase of strength with a partial increase in density, which makes the production of dry mineralization relevant (Zudyaev, Moiseev 1999), (Sanytsky, Iliv, Poznyak, Pavlyshyn 2003).

3. The introduction of ash up to $30 \%$ and dust up to $10 \%$ can increase the strength of foam concrete (Martynenko 2003).

4. The introduction of liquid glass not only improves the properties of technical foam, but also increases the resistance of foam concrete to delamination and shrinkage.

5. To increase the strength and stability of foam concrete can be introduced into the composition of up to $30 \%$ ash and up to $10 \%$ dust and use liquid glass as a stabilizer of this colloidal mixture. 
6. Reducing the amount of water in the mortar mixture, replacing it with an equivalent volume of foam and a possible transition to production of dry mineralization, will improve the properties of foam concrete.

7. This composition of the mixture allows you to get a brand of foam concrete up to $15 \mathrm{kgf} / \mathrm{cm}^{2}$. To increase the brand, it is necessary to switch to the brand of cohesive 500, or increase the cost of cement brand 400 .

\section{References}

Merkin, A. P., Kobidze, T. E. (1988) Features of the structure and basis of the technology for producing effective foam concrete materials. Building materials. No. 3. pp. 16-18.

Zudyaev, E. A., Moiseev, E. A. (1999) Preparation of foam concrete by dry mineralization. Mechanization of construction. Moscow. Vol. 2. pp 2-4. (in Russian).

Bolshakov, V. I., Martynenko, V. A. (2001) Necessary properties of foaming agents for the production of foam concrete. Chemistry and chemical technology issues. Moscow. Vol. 3. pp. 35-39. (in Russian).

Martynenko, V. O. (2003) The tendency of development of production of small artificial products from cellular concrete . Construction of Ukraine. No. 7. pp. 25-28.

Sanytsky, M. A., Iliv, V. V., Poznyak, O. R., Pavlyshyn, I. I. (2003) Foam concrete on modified Portland cements. VIII International Scientific Conference "Actual Problems of Construction and Environmental Engineering". Lviv. pp. 33-36 (in Ukrainian).

Iliv, V. V., Kahanov, V. O. (2005) Research and adjustment of properties of foaming agents. Collection of works "Theory and practice of production and use of aerated concrete in construction". Dnipropetrovsk. Vol. 2 pp 105-107 (in Ukrainian).

Iliv, V. V., Kahanov, V. O., Nazarevych, V. B. (2005) Aspects of the production of non-autoclaved solidified concrete in monolithic construction. 3rd International Internet-conference "State of modern building science-2005" Poltava, 2005. 6 p. 3rd International Internet-conference "State of modern building science-2005" Poltava. 6 p. (in Ukrainian).

Zhaglin, V. I., Artsybashev, G. A. (2005) Experience in mastering the production of aerated concrete using modern technology. Coll. Proceedings of the II-nd international seminar "Theory and practice of production and use of aerated concrete in construction". Release 2. Dnepropetrovsk. PGASA. pp. 27-33.

Bolshakov, V. I., Martynenko, V. A. (2005) Increase in the volume of production and use of autoclaved aerated concrete - the strategic course of Ukraine in construction. Coll. Proceedings of the II-nd international seminar "Theory and practice of production and use of aerated concrete in construction". Release 2. Dnepropetrovsk. PGASA. pp. 13-27.

Shakhova, L. D., Chernositova, E. S. (2005) Rheological characteristics of foam concrete mixtures // Coll. Proceedings of the II International Seminar "Theory and practice of production and use of aerated concrete in construction". Release 2. Dnepropetrovsk. PGASA. Pp. 89-94.

Yurchenko, S.L., Sorokolat, N.V. (2006) Study of the properties of foaming solutions. Works of TDTAU. Vol. 14. T 1. Ternopil. Pp. 65-72 (in Ukrainian).

Borovikov, V. O., Slutskaya, O. M. (2014) On the need to improve regulations on fire protection of facilities with stationary foam fire extinguishing systems. Scientific Bulletin of UkrNDIPB. Kyiv. N 2 (30). pp. $93-98$ (in Ukrainian).

Iliv, V. V., Iliv, Ch.-Dzv. V. (2019) Research of foaming agents for the production of autoclaved foam concrete. Theory and practice of construction. Proceedings of the Lviv Polytechnic National University. Lviv. Vol. 904. pp. $49-57$ (in Ukrainian). 
В. В. Ілів, Х.-Д. В. Ілів

Національний університет “Львівська політехніка", кафедра будівельного виробництва

\section{ДОСЛІДЖЕННЯ ПІНОУТВОРЮВАЧІВ ТА БЕТОНІВ НА ЇХ ОСНОВІ ДЛЯ ВИРОБНИЦТВА ВИРОБІВ БЕЗАВТОКЛАВНОГО ТВЕРДНЕННЯ ТА МОНОЛІТНОГО БЕТОНУВАННЯ}

(С) Ілів В. В., Ілів Х.-Д. В., 2020

Виробництво виробів із пінобетонів та монолітне бетонування з них потребує піноутворювачів, що володіють властивостями отриманої піни з достатнім значенням ії критеріїв (кратності піноутворення, стійкості піни за певний проміжок часу); іiі сумісністю з портландцементом та продуктами його гідратації; з гідратованим вапном тощо. Недостатні властивості піни можуть бути компенсовані введенням коригувальних і стабілізуючих добавок. Хоча досліджені піноутворювачі не є завжди екологічно чистими продуктами, однак їхня незначна концентрація в пінобетонах створює прецедент їхньої незамінності у виробничому процесі.

Досліджені піноутворювачі практично не відрізняються за кратністю та стабільністю під час їхнього використання у 1 \%-му розчині. Найкращі технологічні властивості притаманні пінам, отриманим із піноутворювачів марок ПЕАС та "Пенострем", особливо темного кольору. Введення добавки рідкого скла частково підвищує кратність та стабільність розчину піни. Крім того, випробувана, вона впливає як прискорювач набору міцності на тверднення пінобетонів, що підвищує оборотність металоформ та час навантаження моноліту. Це має особливе значення при серійному виготовлення виробів із пінобетонів природного тверднення.

Встановлено, що склади пінобетонів, які не містять добавки, в основному схильні до розшарування та зсідання, тому при виготовленні з них зразків велику увагу приділяли якості отриманих зразків. Це свідчить про те, що добавка $є$ не тільки стабілізатором піни, вона стабілізує також і пінобетонні суміші, отримані на їхній основі. Введення рідкого скла приводить до зростання міцності пінобетонів при стиску приблизно в 3-4,5 раза у віці зразків 28 діб. При цьому міцність пінобетонів зростає орієнтовно лише в $1,2-1,5$ раза у віці зразків 14 діб. Введення в склад пінобетонів золи до $30 \%$ та пилевиносу до $10 \%$ замість піску теж дає змогу підвищити міцність пінобетонів приблизно в $1,2-1,5$ раза у віці 28 діб. Введення всіх видів добавок дозволило уникнути розшарування та зсідання суміші та стабілізувати значення середньої густини пінобетонів.

Ключові слова: піна, піноутворювач, пінобетон, конструктивні властивості, теплотехнічні властивості, кратність піноутворення, стабільність піни в часі. 